\title{
異方性を示す粘弾性システムの過渡解析とその同定
}

\author{
小林 康 秀*, 沖田 豪*, 田: 中正吾*, 岡 本孝 之*
}

\section{Transient Analysis of Anisotropic Viscoelastic System and Its Identification}

\author{
Yasuhide Kobayashi*, Tsuyoshi Okita*, Shogo Tanaka* and Takayuki Oкamoto*
}

\begin{abstract}
Most of work on the identification theory for viscoelastic systems and its application have been restricted to the isotropic systems. These models are not enough to express all the actual viscoelastic systems because improvements in material properties and more effective engineering capabilities in utilizing anisotropic behavior have made an increase of anisotropy in viscoelastic systems.

In this papar we propose the identification method of three-dimensional hyperbolic distributed parameter: systems with anisotropic viscoelasticity. First of all, we derive the Green function of systems whose boundary conditions are given as one free surface and another fixed surfaces. In this Green function, the eigenvalues coresponding to the free surface are expressed in so complex a manner that we approximate them explicitly for the identification of the system.

The validity of the proposed method has been confirmed by digital simulation and we applied this method to the actual anisotropic viscoelastic system to estimate the system prameters. The results of the estimates from the actual physical system have shown that the proposed method is useful.
\end{abstract}

Key Words: system identification, hyperbolic distributed parameter system, anisotropic viscoelastic system, transient analysis

\section{1. まえがき}

双曲形分布定数系の解析は, 振動現象および波動現 象等を取り扱う上で重要な役割りを果している。この

†第 22 回計測自動制御学会学術講演会で発表 (昭 $58 \cdot 7$ )

* 山口大学工学部 宇部市常盤台 2557

* Faculty of Engineering, Yamaguchi University, Ube

(Received November 1, 1984)

(Revised August 10, 1985)
ような双曲形分布定数系の可制御性, 可観測性, 安定

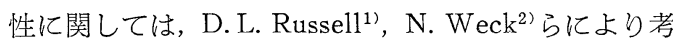
察されている. また，その同定は，単純にモデル化し たシステムについて, 有限要素法, Galerkin 法等 ${ }^{3), 4}$, を用いて検討されている。

先に筆者らは，等方等質の仮定のむとに，三次元双 曲形分布定数系の過渡解析を行い，それに基づくシス テム同定法を提案し，実際の三次元粘弾性システムへ 適用した5)。しかし，現実のシステムは，生成時ある いは工作時の条件により結晶構造に方向性をあち，力 学的性質化異方性を示すあのが多( ${ }^{6), 7)}$. このような 異方性には数多くの種類があるが，こてでは比較的簡 単でよく見受けられる横等方性システムについて考察 する・横等方性を示す物質は，一方向の粘弾性定数の みが異なり, ロール圧延された粘弾性材料, 亜鉛, 緑 柱石などは，乙の性質をむつ ${ }^{6}$. 従来, 横等方二次元 粘弾性システムの周波数解析はなされているが，その 同定については言及されていない(日). しかむ, '周波数 解析の結果を逆フーリエ変換により過渡応答を得るこ とは, 一般に困難である。

そこで本論文では，横等方性三次元双曲形分布定数 系の過渡解析を行ない，その同定法を考える．まず， 実験に適合した境界条件を設定した上で，過渡解析に よりグリーン関数を導出する，自由境界面をすつ異方 性システムの固有值は, システムパラメータを含んだ 複雑な関係式により与えられる. システムの過渡応答 を具体的に得るには，乙れらの関係式を解き，固有值 を求める必要がある.さらに，システム同定を行うに は，未知パラメータを含むてれらの関係式から固有値 を求めなければならない.しかし, 固有值を解析的に 陽表示することは困難であるため，システムパラメー タを用いて固有值を近似陽表示し，システム同定を試 みる. ての近似の妥当性を検証した後, 本方法を実シ ステムへ適用し，システムパラメータを推定する。 


\section{2. システムのモデリング}

微小要素の応力, ひずみ, 変位は, 平衡条件, 運動 関係式および構成方程式により関係づけられる.この 内, 平衡条件, 運動関係式は, 物質の種類とは関係な く同一である、構成方程式は, 応力一ひずみ関係を与 え，ひずみが小さい範囲ではこれらは線形と考えられ る. 一般に, 線形一次元粘弾性システムの応力 $\tau$, ひ ずみ $\varepsilon の$ 関係は, 次式で与えられる ${ }^{9)}$.

$$
\sum_{k^{\prime}=0}^{m} p_{k^{\prime}} \frac{d^{k^{\prime}} \tau}{d t^{k^{\prime}}}=\sum_{k^{\prime \prime}=0}^{n} q_{k^{\prime \prime}} \frac{d^{k^{\prime \prime}} \varepsilon}{d t^{k^{\prime \prime}}}
$$

ただし， $p_{k^{\prime}} ， q_{k^{\prime \prime}}$ はシステムの性質を表わす定数であ る.

ここでは, 固体的性質の強い工学的粘弾性システム 一の適用を目指し，比較的簡単な Voigt モデル $(m=$ $0, n=1)$ を用い上う ${ }^{92}$. さらに，(1)式に重衫合わせ の原理を用いれば， $x$ 軸方向のみに異方性を示す横等 方粘弾性構成方程式として次式を得る ${ }^{10)}$.

$$
\begin{aligned}
& {\left[\begin{array}{l}
\tau_{x x} \\
\tau_{y y} \\
\tau_{z z}
\end{array}\right]=\left[\begin{array}{ccc}
c_{0}+c_{1} & c_{0} & c_{0} \\
c_{0} & c_{0}+c_{2} & c_{0}+c_{3} \\
c_{0} & c_{0}+c_{3} & c_{0}+c_{2}
\end{array}\right]\left[\begin{array}{l}
\varepsilon_{x x} \\
\varepsilon_{y y} \\
\varepsilon_{z x}
\end{array}\right] \text { 軸方向 }} \\
& {\left[\begin{array}{l}
\tau_{y z} \\
\tau_{z x} \\
\tau_{x y}
\end{array}\right]=\left[\begin{array}{ccc}
b_{2} & 0 & 0 \\
0 & b_{1} & 0 \\
0 & 0 & b_{1}
\end{array}\right]\left[\begin{array}{l}
\gamma_{y z} \\
\gamma_{z x} \\
\gamma_{x y}
\end{array}\right] \text { せん断方向 }}
\end{aligned}
$$

ただし，上式に含まれる作用素は次式で与えられる。

$$
\begin{aligned}
& c_{0}=\lambda_{x}+\nu_{x} D_{t} \\
& c_{0}+c_{1}=\left(\lambda_{x}+2 \mu_{x}\right)+\left(\nu_{x}+2 \zeta_{x}\right) D_{t} \\
& c_{0}+c_{2}=(\lambda+2 \mu)+(\nu+2 \zeta) D_{t} \\
& c_{0}+c_{3}=\lambda+\nu D_{t} \\
& b_{1}=\mu_{x y}+\zeta_{x y} D_{t} \\
& b_{2}=\left(c_{2}-c_{3}\right) / 2=\mu+\zeta D_{t}
\end{aligned}
$$

こてで, $D(\cdot) \triangleq \partial / \partial(\cdot)$ であり, $\lambda_{x}, \nu_{x}$ は $x$ 軸方向 のそれぞれ弾性定数, 粘性定数, $\lambda, \nu$ は $y$ 求よび $z$ 軸方向のそれぞれ弾性定数, 粘性定数， $\mu_{x y}, \mu$ はせ

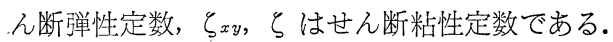

てれまでに，軸方向抢よびせん断方向について，緩 和弹性率を共に求めた例はきわめて少なく ${ }^{111}$ ，粘性が 比較的小さいシステムでは, ポアソン比は定数として いる場合が多い，とこでも，異方性を示す軸方向も含 め, 軸方向, せ九断方向は同じ粘弾性比をむつとす $3^{12), 13)}$.

$$
\frac{\nu_{x}}{\lambda_{x}}=\frac{\zeta_{x}}{\mu_{x}}=\frac{\zeta_{x y}}{\mu_{x y}}=\frac{\nu}{\lambda}=\frac{\zeta}{\mu}=\frac{1}{k}
$$

(3) 式の粘弹性定数は, ポアソン比 $\sigma_{x y}, \sigma_{y x}, \sigma_{y z}$ を 用いてつぎのように表わすととができる。

$$
\begin{aligned}
& \lambda_{x}=k \nu_{x}=\sigma_{x y} E /\left(1-2 \sigma_{x y} \sigma_{y x}-\sigma_{y z}\right) \\
& \mu_{x}=k \zeta_{x}=\sigma_{x y}\left(1-\sigma_{y x}-\sigma_{y z}\right)
\end{aligned}
$$

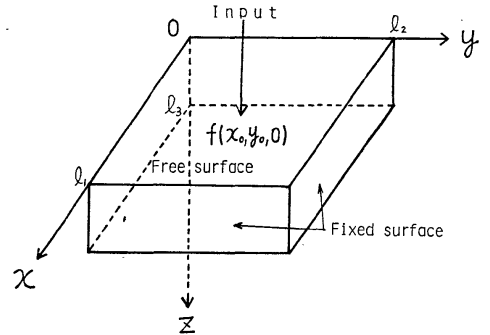

Fig. 1 Boundary condition of system

$$
\begin{gathered}
\times E /\left\{2 \sigma_{y x}\left(1-2 \sigma_{x y} \sigma_{y x}-\sigma_{y z}\right)\right\} \\
\lambda=k \nu=\left(\sigma_{y z}+\sigma_{x y} \sigma_{y x}\right) \\
\\
E /\left\{\left(1+\sigma_{y z}\right)\left(1-2 \sigma_{x y} \sigma_{y x}-\sigma_{y z}\right)\right\} \\
\left.\mu=k \zeta=E /\left\{2\left(1+\sigma_{y z}\right)\right)\right\}
\end{gathered}
$$

ただし，Eは純弾性体におけるYoung 率に対応する。 また，一般的な横等方性システムでは，粘弾性比を含 め 6 つのパラメータが存在する. しかし, 力学的に矛 盾を生じない付加的な関係式がいくつか提案されてお り，ここではつぎの関係があるあのとしよう77.

$$
\frac{b_{2}}{b_{1}}=\sigma_{y x}+\frac{1-\sigma_{y z}}{2}+\frac{\sigma_{y x}\left(1-\sigma_{x y} \sigma_{y x}\right)}{2 \sigma_{x y}\left(1+\sigma_{y z}\right)}
$$

対象とするシステムの密度を $\rho$ に, $x, y$ ，および $z$ 軸方向の変位をそれぞれ $u, v ， w$ としよう. (1), (2)式之平衡条件, 運動関係式より, 横等方性三次元 粘弾性システムは, つぎの双曲形偏微分方程式で表わ される.

$$
\begin{aligned}
& \begin{array}{c}
{\left[\rho D_{t}^{2}-\left(c_{0}+c_{1}\right) D_{x}^{2}-b_{1} D_{y}^{2}-b_{1} D_{z}^{2}\right.} \\
-\left(c_{0}+b_{1}\right) D_{x} D_{y} \\
-\left(c_{0}+b_{1}\right) D_{x} D_{z} \\
-\left(c_{0}+b_{1}\right) D_{x} D_{y} \\
\rho D_{t}^{2}-b_{1} D_{x}^{2}-\left(c_{0}+c_{2}\right) D_{y}^{2}-b_{2} D_{z}^{2}
\end{array} \\
& -\left(c_{0}+c_{3}+b_{2}\right) D_{y} D_{z} \\
& -\left(c_{0}+b_{1}\right) D_{x} D_{z} \\
& -\left(c_{0}+c_{3}+b_{2}\right) D_{y} D_{z} \\
& \left.\rho D_{t}^{2}-b_{1} D_{x}^{2}-b_{2} D_{y}^{2}-\left(c_{0}+c_{2}\right) D_{z}^{2}\right]\left[\begin{array}{c}
v \\
w
\end{array}\right]=0 \\
& 0 \angle t, 0 \angle x \angle l_{1}, 0 \angle y \angle l_{2}, 0 \angle z \angle l_{3}(7)
\end{aligned}
$$

つぎに，境界条件について考察しよう. Fig. 1 に 示すような直方体に扔いて，上表面は自由境界面と し, その 1 点 $\left(x_{0}, y_{0}, 0\right)$ にインパルス状の加振入力を 加える．また，他の側面および底面は支持物等を想定 し固定端とする，境界条件を定式化すると，自由境界 面では軸応力およびせん断応力が零である.

$$
\begin{aligned}
& \left.\tau_{z x}\right|_{z=0}=0 \\
& \left.\tau_{z y}\right|_{z=0}=0 \\
& \left.\tau_{z z}\right|_{z=0}=f_{0} \cdot \delta\left(x-x_{0}\right) \cdot \delta\left(y-y_{0}\right) \cdot \delta(t)
\end{aligned}
$$

ただし， $f_{0}$ は入力の大きさを表わす定数で， $\delta(t)$ は単 位インパルスである，固定端では，変位が零である. 
また、インパルス応答を導出するため, 初期条件は 零とする

\section{3. システムの過渡解析}

\section{1 グリーン関数の導出}

(7) 式で与えられる横等方粘弾性システムの運動方 程式より, 一般解を求め, 設定した境界条件, 初期条 件のもとでグリーン関数を導出しよう。（7)式からわ かるように，変位 $u ， v ， w$ が恒等的に零でないため には， (7) 式の作用素行列の行列式が零でなければな らない:このことおよび (3)，(6)式を考虑すれば， 次式が得られる。

$$
\begin{aligned}
& \left\{\rho D_{t}^{2}-b_{1}\left(D_{x}^{2}+D_{y}^{2}+D_{z}^{2}\right)\right\} \\
& \left\{\rho D_{t}^{2}-b_{1} D_{x}^{2}-b_{2}\left(D_{y}^{2}+D_{z}^{2}\right)\right\} \\
& \quad \times\left\{\rho D_{t}^{2}-\left(c_{0}+c_{1}\right) D_{x}^{2}-\left(c_{0}+c_{2}\right)\left(D_{y}^{2}+D_{z}^{2}\right)\right\}=0
\end{aligned}
$$

上式は， $x, y, z$ 軸方向の変位 $u, v, w$ につて 同様であるから，まず $x$ 軸方向の変位 $u$ について考え よう.（9) 式の各因数に対する解を $u_{i}(i=1,2,3)$ とす れば, 変数分離法により，(9)式の解はそれぞれ $x$, $y, z, t$ の関数 $X_{i}, Y_{i}, Z_{i}, T_{i}$ を用いつぎのよう に表わされる。

$$
\begin{aligned}
& D_{x}^{2} X_{i}+\xi_{i}^{2} X_{i}=0, \quad 0 \angle x \angle l_{1} \\
& D_{y}^{2} Y_{i}+\eta_{i}^{2} Y_{i}=0, \quad 0 \angle y \angle l_{2}, \quad i=1,2,3 \\
& D_{z}^{2} Z_{i}+\psi_{i}^{2} Z_{i}=0, \quad 0 \angle z \angle l_{3} \\
& \rho D_{t}^{2} T_{1}+b_{1}\left(\xi_{1}^{2}+\eta_{1}^{2}+\phi_{1}^{2}\right) T_{1}=0 \\
& \rho D_{t}^{2} T_{2}+\left\{b_{2} \xi_{2}^{2}+b_{2}\left(\eta_{2}^{2}+\psi_{2}^{2}\right)\right\} T_{2}=0 \\
& \rho D_{t}^{2} T_{3}+\left\{\left(c_{0}+c_{1}\right) \xi_{3}^{2}+\left(c_{0}+c_{2}\right)\left(\eta_{3}^{2}+\phi_{3}^{2}\right)\right\} T_{3}=0
\end{aligned}
$$

ここで， $\xi_{i}, \eta_{i}, \phi_{i}$ は境界条件により定まる固有值で ある。

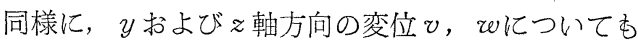
求め，(9)式に代入すれば，つぎの一般解を得る.

$$
\begin{aligned}
& u=\sum_{i=1}^{3} u_{i}=\sum_{i=1}^{3} A_{i} X_{i} Y_{i} Z_{i} T_{i}, A_{1}=1 \\
& v=\sum_{i=1}^{3} v_{i}=\sum_{i=1}^{3} A_{i}^{\prime} \frac{D_{x} X_{i}}{j \xi_{i}} \frac{D_{y} Y_{i}}{j \eta_{i}} Z_{i} \cdot T_{i} \\
& w=\sum_{i=1}^{3} w_{i}=\sum_{i=1}^{3} A_{i}^{\prime \prime} \frac{D_{x} X_{i}}{j \xi_{i}} Y_{i} \frac{D_{z} Z_{i}}{j \phi_{i}} T_{i}
\end{aligned}
$$

こてで， $j=\sqrt{-1}$ ，また， $A_{i}, A_{i}^{\prime}, A_{i}^{\prime \prime}$ は境界条件に よって定まる実数または純虚数であり，つぎの関係が ある。

$$
\begin{aligned}
& \left(c_{0}+c_{1}-b_{1}\right) \xi_{1} A_{1}+\left(c_{0}+b_{1}\right)\left(\eta_{1} A_{1}^{\prime}+\phi_{1} A_{1}^{\prime \prime}\right)=0 \\
& \left(c_{0}+b_{1}\right) \xi_{1} \eta_{1} A_{1}+\left(c_{0}+c_{2}-b_{1}\right) \eta_{1}^{2} A_{1}^{\prime} \\
& \quad-\left(b_{1}-b_{2}\right) \phi_{1}^{2} A_{1}^{\prime}+\left(c_{0}+c_{2}-b_{2}\right) \eta_{1} \psi_{1} A_{1}^{\prime \prime}=0 \\
& \left(c_{0}+b_{1}\right) \xi_{2} A_{2}+\left(c_{0}+c_{2}-b_{2}\right)\left(\eta_{2} A_{2}^{\prime}+\phi_{2} A_{2}^{\prime \prime}\right)=0
\end{aligned}
$$

$$
\begin{aligned}
& \left(c_{0}+c_{1}-b_{1}\right) \xi_{2}^{2} A_{2}+\left(b_{1}-b_{2}\right)\left(\eta_{2}+\psi_{2}^{2}\right) A_{2} \\
& \quad+\left(c_{0}+b_{1}\right) \xi_{2}\left(\eta_{2} A_{2}^{\prime \prime}+\psi_{2} A_{2}^{\prime \prime}\right)=0 \\
& \left(c_{0}+c_{2}-b_{1}\right)\left(\eta_{3}^{2}+\psi_{3}^{2}\right) A_{3} \\
& \quad-\left(c_{0}+b_{1}\right) \xi_{3}\left(\eta_{3} A_{3}^{\prime}+\phi_{3} A_{3}^{\prime \prime}\right)=0 \\
& \left(c_{0}+b_{1}\right) \xi_{3} \eta_{3} A_{3}+\left(c_{0}+c_{2}-b_{2}\right) \eta_{3}\left(\psi_{3} A_{3}^{\prime}-\eta_{3} A_{3}^{\prime \prime}\right) \\
& \quad-\left(c_{0}+c_{1}-b_{1}\right) \xi_{3} A_{3}^{\prime \prime}=0
\end{aligned}
$$

つぎに，境界条件より固有関数を導出しよう. 固定 端での境界条件より, 固有值 $\xi, \eta$ は次式で与えられ. る.

$$
\begin{aligned}
& \xi_{n}=\xi_{i n}=n \pi / l_{1}, \quad n=1,2,3 \cdots \\
& \eta_{m}=\eta_{i m}=m \pi / l_{2}, \quad m=1,2,3 \cdots
\end{aligned}
$$

また，自由境界面の境界条件より， $\psi_{1} ， \psi_{2} ， \psi_{3}$ にはつ ぎの関係があるととがわかる。

$$
\begin{aligned}
& b_{2} \psi_{2 n m}^{2}=b_{1} \psi_{1 n m}^{2}+\left(b_{1}-b_{2}\right) \eta_{m}^{2} \\
& \left(c_{0}+c_{2}\right) \psi_{3 n m}^{2}=\left(b_{1}-c_{0}-c_{2}\right)\left(s_{1}^{2} \xi_{n}^{2}+\eta_{m}^{2}\right)+b_{1} \psi_{1 n m}^{2}
\end{aligned}
$$

$\xi_{n}^{2} \psi_{3 n m}\left\{c_{0}\left(\eta_{m}^{2}+\psi_{1 n m}^{2}\right)-\left(c_{0}+c_{3}\right) s_{1} \eta_{m}^{2}-\left(c_{0}+c_{2}\right) s_{1} \psi_{1 n m}^{2}\right\}$ $\times\left\{\left(s_{1}-1\right) \eta_{m}^{2}-\left(s_{1}+1\right) \psi_{2 n m}^{2}\right\} \cot \left(\psi_{1 m m} l_{3}\right) \tan \left(\psi_{3 n m} l_{3}\right)$ $+2\left(c_{2}-c_{3}\right) \eta_{m}^{2} \psi_{1 n m} \psi_{2 n m} \psi_{3 n m}\left(s_{1}^{2} \xi_{n}^{2}+\eta_{m}^{2}+\psi_{1 n m}^{2}\right)$ $\cot \left(\phi_{2 n m} l_{3}\right) \tan \left(\phi_{3 n m} l_{3}\right)$

$=\phi_{1 n m}\left\{c_{0} s_{1} \xi_{n}^{2}+\left(c_{0}+c_{3}\right) \eta_{m}^{2}+\left(c_{0}+c_{2}\right) \psi_{3 n m}^{2}\right\}$ $\times\left\{\left(\eta_{m}^{2}+\psi_{1 n m}^{2}\right)\left(\phi_{2 n m}^{2}-\eta_{m}^{2}\right)-s_{1} \xi_{n}^{2}\left(\eta_{m}^{2}+\psi_{2 n m}^{2}\right)\right\}$

ただし， $s_{1} \triangleq\left(c_{0}+c_{1}-b_{1}\right) /\left(c_{0}+b_{1}\right)$ である

(15) ～(17) 式より, 自由境界面に対する固有值 $\phi_{i n m}$ は，システムパラメータ $\sigma_{x y}, \sigma_{y z}, \sigma_{y x}$ を含複雑な 関係で与えられる. これについては, 後に述べる.

これらの固有值に対する固有関数は，それぞれ次式 で与えられる。

$$
\begin{aligned}
& X_{n} \triangleq X_{i n}=2 j \sin \left(\xi_{n} x\right) \\
& Y_{m} \triangleq Y_{i m}=2 \cos \left(\eta_{m} y\right) \\
& Z_{i n m} \triangleq 2 e^{j \psi_{i n m} l_{3}} \cos \left\{\psi_{i n m}\left(z-l_{3}\right)\right\}, \quad i=1,2,3(18)
\end{aligned}
$$

また，時間関数 $T_{i n m}$ は (10) 式および初期条件により, 次式で与えられる.

$$
T_{n m} \triangleq T_{i n m}=\frac{K_{n m}}{\rho \omega_{n m}} \cdot e^{-\gamma_{n m} t} \sin \left(\omega_{n m} t\right)
$$

ここで, 減衰定数 $\gamma_{n m}$, 固有角振動数 $\omega_{n m}$, ゲイン $K_{n m}$ はそれぞれ次式で与えられる。

$$
\begin{aligned}
& \gamma_{n m}=\left(\xi_{n}^{2}+\eta_{m}^{2}+\phi_{1 n m}^{2}\right) \zeta / 2 \rho \\
& \omega_{n m}=\frac{\left[\left(\xi_{n}^{2}+\eta_{m}^{2}+\psi_{1 n m}^{2}\right)\left\{4 \rho \mu-\left(\xi_{n}^{2}+\eta_{m}^{2}+\psi_{1 n m}^{2}\right) \xi^{2}\right\}\right]^{1 / 2}}{2 \rho}
\end{aligned}
$$

$K_{n m}=$

$$
\begin{aligned}
& \frac{-b_{1}\left(\xi_{n}^{2}+\eta_{m}^{2}+\psi_{1 n m}^{2}\right)}{4 l_{1} l_{2}\left(\left.c_{2} \xi_{n}^{2} \sum_{i=1}^{3} A_{i} Z_{i n m}\right|_{z=0}+\left.2 b_{2} \xi_{n} \eta_{m} \sum_{i=1}^{3} A_{i}^{\prime} Z_{i n m}\right|_{z=0}\right)} \\
& \times \int_{0}^{l_{1}} \int_{0}^{l_{2}} f_{0} \cdot \delta\left(x-x_{0}\right) \cdot \delta\left(y-y_{0}\right) D_{x} X_{n} Y_{m} d y d x
\end{aligned}
$$


一方，自由端でのせん断応力条件より， $A_{i}, A_{i}^{\prime}, A_{i}^{\prime \prime}$ 记はつぎの関係がある.

$$
\begin{aligned}
& \left.\sum_{i=1}^{3} \phi_{i n m} A_{i n m} D_{z} Z_{i n m}\right|_{z=0}+\left.\sum_{i=1}^{3} \xi_{n} A_{i n m}^{\prime \prime} D_{z} Z_{i n m}\right|_{z=0}=0 \\
& \left.\sum_{i=1}^{3} \phi_{i n m} A_{i n n m}^{\prime} D_{z} Z_{i n m}\right|_{z=0}+\left.\sum_{i=1}^{3} \eta_{m} A_{i n m}^{\prime \prime} D_{z} Z_{i n m}\right|_{z=0}=0
\end{aligned}
$$

上式および(12)式より， $A_{i}, A_{i}^{\prime}, A_{i}^{\prime \prime}(i=1,2,3)$ が求め られる。

以上の上うにして，横等方三次元粘弾性システムの グリーン関数を得ることができる.

$$
\begin{aligned}
u= & \sum_{n, m} 8 j \sin \left(\xi_{n} x\right) \cos \left(\eta_{m} y\right) T_{n m} \\
& \times \sum_{i=1}^{3} A_{i n m} e^{j \psi_{i n m} l_{3}} \cos \left(\psi_{i n m}\left(z-l_{3}\right)\right) \\
v= & \sum_{n, m} 8 j \cos \left(\xi_{n} x\right) \sin \left(\eta_{m} y\right) T_{n m} \\
& \times \sum_{i=1}^{3} A_{i n m}^{\prime} e^{j \psi_{i n m} l_{3}} \cos \left(\psi_{i n m}\left(z-l_{3}\right)\right) \\
w= & \sum_{n, m} 8 j \cos \left(\xi_{n} x\right) \cos \left(\eta_{m} y\right) T_{n m} \\
& \times \sum_{i=1}^{3} A_{i n m}^{\prime \prime} e^{j \psi_{i n m} l_{3}} \sin \left(\phi_{i n m}\left(z-l_{3}\right)\right)
\end{aligned}
$$

\section{2 固有值の近似陽表示}

前節では，横等方三次元粘弾性システムのグリーン 関数を導出した. これを用いてシステムの応答を具体 的に得るには，(15) （17) 式に含まれる固有值を求め る必要がある。しかし，乙れらの固有值は複雑な非線 形関係で示され，解析的得るととは困難である，そ のため数值解法に依らざるを得ないが，それぞれの固 有値の組合せについて非線形最適化手法を適用するこ とは，ばく大な計算量を必要とする，さらにてててで 目的とするシステム同定に際しては，未知パラメータ $\cdot \sigma_{x y}, \sigma_{y z}, \sigma_{y x}$ を含むこれらの非線形連立方程式から 固有値 $\psi_{i n m}(i=1,2,3)$ を求めなければならない。 そと で，固有值をシステムパラメータを用い近似陽表示す るととを考えよう。

(13)，(14) 式より，固有値 $\xi_{n}, \eta_{m}$ は， $n, m$ と之 屯に大きくなり，それらに対応する $z$ 軸方向の固有値

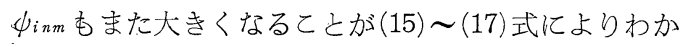
る.さらに, $\xi_{n}, \eta_{m} \rightarrow \infty$ のとき, $\phi_{i n m} \rightarrow j \infty$ となるた め, 近似ずる固有值 $\phi_{i n m}$ を有界な值で表現する必要 がある、そのため，等方等質のシステムに対しては， $\alpha\left(\xi_{n}, \eta_{m}\right)=\phi_{1 n m}^{2} /\left(\xi_{n}^{2}+\eta_{m}^{2}\right)$ を定義し, 固有値の近似を可 能にした ${ }^{5)}$. しかし， こてで対象とするシステムは， $x$ 軸方向に異方性を示すので，(15) (17) 式に含まれ る因数 $\left(s_{1}^{2} \xi_{n}^{2}+\eta_{m}^{2}\right)$ を用い次式を定義しよう.

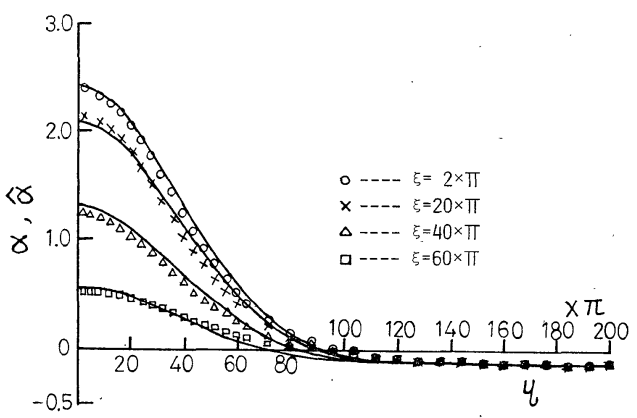

Fig. 2 Exact eigenvalue and its approximation

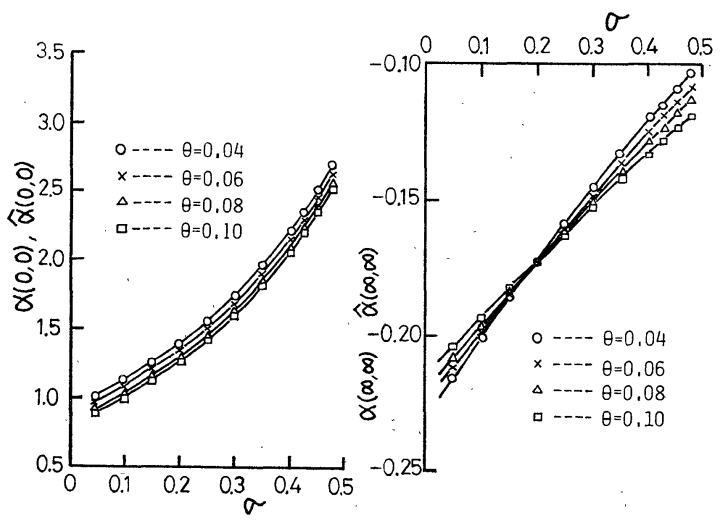

Fig. 3 Numerical solution of $\alpha(0,0), \alpha(\infty, \infty)$ and these approximations

$$
\alpha\left(\xi_{n}, \eta_{m}\right) \triangleq \phi_{1 n m}^{2} /\left(s_{1}^{2} \xi_{n}^{2}+\eta_{m}^{2}\right)
$$

等方等質のシステムでは， $c_{1}=2 b_{1}$ であるため, $s_{1}=1$ となる。また（15)〜 (17)式に含まれるポアソン比 $\sigma_{x y}, \sigma_{y x}, \sigma_{y z}$ を $\sigma_{y z}$ を基準にして次式で表わそう.

$$
\sigma_{y z} \triangleq \sigma, \quad \sigma_{x y} \triangleq \sigma\left(1+\theta_{1}\right), \quad \sigma_{y x} \triangleq \sigma\left(1-\theta_{2}\right)
$$

ここで， $\theta_{1}, \theta_{2}$ は異方性の度合いを表少すパラメータ で $\theta_{1}=\theta_{2}=0$ のとき，等方等質なシステムを表わす.

(22)式で定義される $\alpha\left(\xi_{n}, \eta_{m}\right)$ を近似するため, ま ず $\theta_{1}=\theta_{2}=\theta$ の場合について, (15) 〜 (17) 式より $\alpha\left(\xi_{n}\right.$, $\left.\eta_{m}\right)$ ）の数值解を得よう.

非線形最適化手法の初期設定值飞等方等質の近似 解5)用い，ポアソン比が物理的意味をむつ $0 \angle \sigma \angle$ 0.5 の範囲で求めた解 $\alpha\left(\xi_{n}, \eta_{m}\right)$ を一例として示せば,

Fig. 2 の各点となる. また, 固有值 $\xi_{n}$ についても, 数值解 $\alpha\left(\xi_{n}, \eta_{m}\right)$ はFig. 2 と同様な傾向を示す. Fig. 2 は, 解 $\alpha\left(\xi_{n}, \eta_{m}\right)$ が固有値 $\xi_{n}, \eta_{m}$ について指数関数 的な変化を示し， $\xi_{n}, \eta_{m}$ の増加と共に一定值に漸近 するととを示している．乙れらの傾向は，種々のパラ メータをあつシステムについてあ同様である. そこ で, 数值解 $\alpha\left(\xi_{n}, \eta_{m}\right)$ を指数関数を基幹としたエルミ 一ト多項式で展開表現しよう. 


\section{2 昭和 60 年 12 月}

$$
\hat{\alpha}\left(\xi_{n}, \eta_{m}\right)=\sum_{j_{1}=0}^{M} \sum_{j_{2}=0}^{M} c_{j_{1} j_{2}} H_{j_{1} j_{2}}\left(\xi_{n}, \eta_{m}\right) \alpha^{*}\left(\xi_{n}, \eta_{m}\right)
$$

ここで, $H_{j_{1} j_{2}}$ は二次元のエルミート多項式であり， $c_{j_{1} j_{2}}$ は $H_{j_{1} j_{2}}$ の直交性より定まる展開係数である. また, $\alpha^{*}\left(\xi_{n}, \eta_{m}\right)$ は基幹となる指数関数であり, 次式 で定義される.

$$
\begin{aligned}
& \alpha^{*}\left(\xi_{n}, \eta_{m}\right) \\
& =\{\hat{\alpha}(0,0)-\hat{\alpha}(\infty, \infty)\} e^{-\left(\hat{d}_{1} \xi_{n}{ }^{2}+\hat{d}_{2} \eta_{m}{ }^{2}\right) l_{3}{ }^{2}+\hat{\alpha}(\infty, \infty)}
\end{aligned}
$$

ここで, $\hat{\alpha}(0,0), \hat{\alpha}(\infty, \infty)$ はポアソン比 $\sigma_{x y}, \sigma_{y x}, \sigma_{y z}$ の関数であり, 種々のパラメータのシステムについ て，(15)〜(17) 式により求めると, Fig. 3 の各点と して得られる.てれらは, 二次近似可能であり, 最小 二乗法によりつぎのように近似される。

$$
\begin{aligned}
\hat{\alpha}(0,0)= & 1.04024+1.20702 \sigma_{y z}+5.15861 \sigma_{y z}^{2} \\
& -1.95797 \theta+1.55092 \theta^{2}-2.08901 \sigma_{y z} \cdot \theta \\
\hat{\alpha}(\infty, \infty)= & -0.234396+0.332078 \sigma_{y z}-0.052918 \sigma_{y z}^{2} \\
& +0.121967 \theta+0.699399 \theta^{2}-1.04952 \sigma_{y z} \cdot \theta
\end{aligned}
$$

同様に，パラメータ $d_{1}, d_{2}$ はつぎのように近似され る.

$$
\begin{aligned}
\hat{d}_{1}= & 0.187017-0.197824 \sigma_{y z}+0.743672 \sigma_{y z}^{2} \\
& -0.122496 \theta+0.811145 \theta^{2}+0.344620 \sigma_{y z} \cdot \theta \\
\hat{d}_{2}= & 0.194956-0.111776 \sigma_{y z}-0.946998 \sigma_{y z}^{2} \\
& +0.263170 \theta-0.123414 \theta^{2}+0.171494 \sigma_{y z} \cdot \theta
\end{aligned}
$$

乙の $\hat{\alpha}(0,0), \hat{\alpha}(\infty, \infty), \hat{d}_{1}, \hat{d}_{2}$ を用い, 基幹項 $\alpha^{*}\left(\xi_{n}\right.$, $\left.\eta_{m}\right)$ のみで表わした $\hat{\alpha}\left(\xi_{n}, \eta_{m}\right)$ を Fig. 2 に実線で示 す. Fig. 2 より, 基幹項のみであ $\alpha\left(\xi_{n}, \eta_{m}\right)$ はほぼ近 似可能と考えられる. また， $\theta_{1} \neq \theta_{2}$ のシステムについ ても同様に近似可能と考えられる.

このようにして, 固有值 $\phi_{1 n m}$ にかかわる $\alpha\left(\xi_{n}, \eta_{m}\right)$ が近似陽表示できれば, 自由境界面に対する他の固有 值 $\psi_{2 n m}, \phi_{3 n m}$ は，(15)，（16)式より簡単に求めるこ とができる.

\section{4. システム同定}

前章では, システムのグリーン関数を導出し, 複雑 に関係している固有值を近似的に陽表示した. 実シス テムでは, システムパラメータのうち, 形状を表わす 大きさ $l_{1}, l_{2}, l_{3}$ および密度 $\rho$ は容易に知ることがで きる場合が多い. しかし, 弾性定数 $\mu$, 粘性定数 $\zeta$, ポアソン比 $\sigma_{x y}, \sigma_{y z}, \sigma_{y x}$ は一般に未知である場合が 多い. 粘弾性システムのこれら力学的性質を系統的に 測定する方法はないようであるが，乙れらのシステム
第 21 巻 第 12 号

パラメータは，応答波形の伝播速度あるいは固有振動 数などに深く関係しており，その推定は振動系の解析 および設計等, 工学的に重要である. そこで, てれら のパラメータをシステムの過渡応答波形より, 系統的 に推定する問題を考える.

いま, 実システムの過渡応答波形の振動変位, 振動 速度, 振動加速度の観測值を $\boldsymbol{m}$ とする.

$$
\boldsymbol{m} \triangleq\left(u, v, w, D_{t} u, D_{t} v, D_{t} w, D_{t}^{2} u, D_{t}^{2} v, D_{t}^{2} w\right)^{T}
$$

乙の観測值 $\boldsymbol{m}$ は一般に暗振動および雑音で污されて いる. したがって，(21)式のグリーン関数により得ら れる理論波形を $\hat{\boldsymbol{u}}$ とし, つぎの評価量のもとでパラメ 一夕推定を行う.

$$
J=\int_{\boldsymbol{T}} \int_{\boldsymbol{R}}(\hat{\boldsymbol{u}}-\boldsymbol{m})^{T} \boldsymbol{A}(\hat{\boldsymbol{u}}-\boldsymbol{m}) d \boldsymbol{x} d t
$$

ただし， $\boldsymbol{T}$ は観測時間， $\boldsymbol{R}$ は観測領域， $\boldsymbol{A}$ は重み行 列である.

振動による物体の破損, 破壊は主に速度成分に関係 し，人体に影響を与えるのは主に加速度成分といわれ ている. したがって, 重み行列 $\boldsymbol{A}$ は, モデルの使用目 的および雑音の統計的性質を反咉して選定する必要が ある、また，評価量 (28) 式の最小化は非線形最適化問 題となり，複数の極值が存在することがある. そのた め, 最適化手法においては，適切な初期設定值を与え る必要がある、これらは，等方等質なシステムにおけ る初期值設定法を用いるととが考えられる

\section{5. 実験的考察}

\section{1 ディジタルシミュレーション}

まず，本同定法の理論的正当性をシミュレーション により検討する. 導出したグリーン関数(21)式によ り，具体的飞過渡応答波形を求めよう。

防振系などに用いられる工学的粘弾性材料を想定し システムの各パラメータをそれぞれ $l_{1}=l_{2}=1.0 \mathrm{~m}$, $l_{3}=0.01 \mathrm{~m}, \rho=1.60 \times 10^{3} \mathrm{~kg} \cdot \mathrm{m}^{-3}, \zeta=2.70 \times 10^{2} \mathrm{~kg} \cdot$

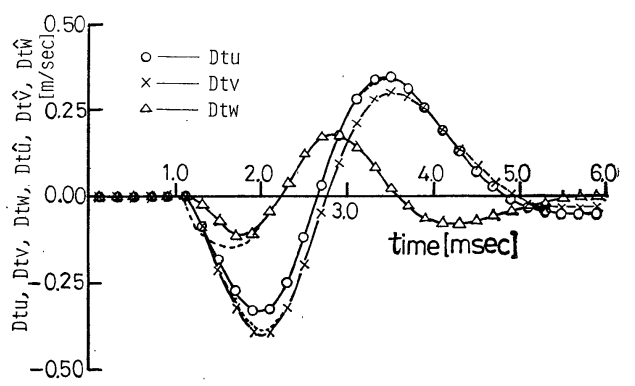

Fig. 4 Transient response by exact eigenvalues. and estimated response by approximated eigenvalues 
Table 1 Estimated parameters from noisy data

\begin{tabular}{|c|c|c|c|c|c|c|}
\hline \multirow[t]{2}{*}{ Parameters } & & $\begin{array}{c}\text { elastic } \\
\text { constants }\end{array}$ & $\begin{array}{l}\text { viscosity } \\
\text { coefficients }\end{array}$ & \multicolumn{3}{|c|}{ Poisson's ratios } \\
\hline & & $\mu\left[\mathrm{kg} / \mathrm{ms}^{2}\right]$ & $\zeta[\mathrm{kg} / \mathrm{ms}]$ & $\sigma_{x y}$ & $\sigma_{y z}$ & $\sigma_{y x}$ \\
\hline True values & & $0.100 \times 10^{7}$ & 270 & 0.486 & 0.450 & 0.414 \\
\hline \multirow{3}{*}{$\begin{array}{l}\text { Estimated } \\
\text { values }\end{array}$} & Noise-free & $0.101 \times 10^{7}$ & 271 & 0.483 & 0.446 & 0.409 \\
\hline & $R_{v}=0.05$ & $0.103 \times 10^{7}$ & 273 & 0.480 & 0.437 & 0.393 \\
\hline & $R_{v}=0.10$ & $0.102 \times 10^{7}$ & 277 & 0.480 & 0.440 & 0.400 \\
\hline
\end{tabular}

$\mathrm{m}^{-1} \cdot \mathrm{s}^{-1}, \quad \mu=1.00 \times 10^{6} \mathrm{~kg} \cdot \mathrm{m}^{-1} \cdot \mathrm{s}^{-2}, \quad \sigma_{x y}=0.486, \quad \sigma_{y z}$ $=0.450, \sigma_{y x}=0.414$ とする. 加振点および観測点は, 異方性の影響を明らかにするため対称性をむたせ, 自

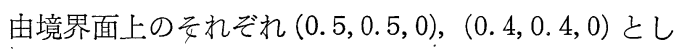
た.（15)〜 (17) 式により与えられる固有值の㛜密解 (数值解) を用いた場合, システムの $x, y ; z$ 軸方向 のインパルス応答（振動速度） $D_{t} u, D_{t} v, D_{t} w$ を Fig. 4 亿実線で示す.なお，本例の固有值は，いず れも，収束性と計算時間を考慮し $n=m=200$ までを 用いた．観測点に対称性をむたせているため，システ 厶が等方等質性であれば， $x$ および $y$ 軸方向の振動速 度 $D_{t} u ， D_{t} v$ は等しくなるが，異方性のため Fig. 4 のように異なった応答を示している。

つぎに，固有值の近似の妥当性を確認するため, 上 述のシステムパラメータについて, 近似固有值を用い 応答波形を求めた.（24)式の基幹項（初項）のみで固 有值を近似した場合においても，応答波形は Fig. 4 の敩密な固有值を用いた応答波形とほぼ一致した.

さらに，本方法によりシステム同定が可能かどうか を調べるため，厳密解による応答波形を与え，近似陽 表示した固有值による応答波形より，システムパラ メータを推定した. パラメータ推定のための評洒量は (28) 式をサンプリング周期 $\Delta=0.1 \times 10^{-3} \mathrm{sec}$ で離散化 し，振動速度成分のみに着目するように重み行列 $\boldsymbol{A}$ を 選定した。 また，一点観測なので変数 $x, y, z$ は省 略する.

$$
\begin{aligned}
J= & \sum_{k=10}^{60}\left[\left\{D_{t} \hat{u}(k \Delta)-D_{t} u(k \Delta)\right\}^{2}\right. \\
& +\left\{D_{t} \hat{v}(k \Delta)-D_{t} v(k \Delta)\right\}^{2} \\
& \left.+\left\{D_{t} \hat{v}(k \Delta)-D_{t} w(k \Delta)\right\}^{2}\right]
\end{aligned}
$$

また，上式の最適化には Fletcher-Powell 法を用い， その初期設定值には，等方等質なシステムに対する 決定法を用いた。 その際, 固有值の近似式 (24) は基幹 項のみを用いた. 得られた各パラメータの推定值を Table 1 亿，推定波形を Fig. 4 亿破線で示す. この 推定波形は, 時間 $t$ 㤎小さい部分で厳密な固有值によ る応答波形と多少䛊差を生じているが，他の部分はほ ぼ一致している，また，Table 1 より明らかなよう

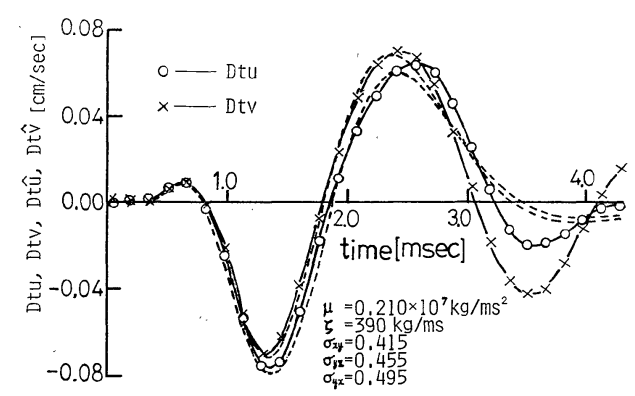

Fig. 5 Actual response of anisotropic viscoelastic system and estimated response

に，固有值を近似陽表示したととによる各パラメータ の推定䛊差は数パーセント以内である. 実際のシステ ムでは, 観測值は暗振動, 雑音等で污されている. そ こで, 理論応答波形に平均零, 分散 $\sigma_{v}^{2}$ の白色正規性 雑音を加え, 観測値とした. その際, SN 比に関して,

$$
R_{v}=\sqrt{\frac{3 \times(60-9) \cdot \sigma_{v}^{2}}{\sum_{k=10}^{60}\left\{\left(D_{t} u(k \Delta)\right)^{2}+\left(D_{t} v(k \Delta)\right)^{2}+\left(D_{t} w(k \Delta)\right)^{2}\right\}}}
$$

を考え， $R_{v}=0.05,0.10$ となるように $\sigma_{v}^{2}$ を設定し， 同様に推定した結果を Table 1 に示す.

観測值に雑音が加わっている場合も推定誤差は数パ 一セントで, 本方法によりシステム同定が可能と考え られる。

\section{2 実システムへの適用}

てれまでに，異方性を示す三次元双曲形分布定数系 のグリーン関数を導出し, システム同定法の妥当性を ディジタルシミュレーションにより検討した，ここで 时, 異方性を示す工学的粘弾性システムとしてクロロ プレンゴムを取り上げ，その実測応答波形からパラメ ータ推定を行う.

大きさ $l_{1}=l_{2}=1.0 \mathrm{~m}, l_{3}=0.00977 \mathrm{~m}$, 密度 $\rho=$ $1.565 \times 10^{3} \mathrm{~kg} \cdot \mathrm{m}^{-3}$ なるクロロプレンゴムの側面およ び底面を固定する. 加振入力は, 重さ $30.8 \mathrm{~g}$.の鍾を $(0.5,0.5,0)$ の自由境界上に高さ $0.5 \mathrm{~cm} よ り$ 自然落 下させることにより得た，乙の入力は，完全なインパ ルスではないが, 応答の振動周期に比べ小さいとみな すととができる. 波形の観測には，いわゆる波の腹に 


\section{4 昭和 60 年 12 月}

相当する $(0.4,0.4,0)$ の自由境界面上に振動ピック アップを設置し， $x$ および $y$ 軸方向の振動速度 $D_{t} u$, D。を観測する．またてれと同時に，釷の上端部に加 振入力および加振時刻を検知するための振動ピック アップを設けた．とのときの応答波形 $D_{t} u ， D_{t} v$ を Fig. 5 に実線で示す. パラメータ推定のための評価 量はシミュレーション例と同様にして次式を用いた。

$$
\begin{aligned}
J= & \sum_{k=10}^{110}\left[\left\{D_{t} \hat{u}(k \Delta)-D_{t} u(k \Delta)\right\}^{2}\right. \\
& \left.+\left\{D_{t} \hat{v}(k \Delta)-D_{t} v(k \Delta)\right\}^{2}\right]
\end{aligned}
$$

ただし， $\Delta=5 / 128 \mathrm{msec}$ である。

最適化の初期值設定法, 固有值の近似およびその項 数 $n, m(=200)$ は, 前節のシミュレーションと同様に してパラメータ推定を行った.

得られたパラメータの推定值を Fig. 5 中に記し， その推定波形を破線で示す。乙の推定波形は，異方性 を示すシステムの実測応答波形の主要部分を大略説明 して抢り，設定したモデルおよびグリーン関数は，異 方性を示す実システムを表わしていると考えられる. また各パラメータの推定值も，システムがゴム系であ るととを考慮すれば，ほぼ妥当である．したがって， 本方法により，横等方三次元粘弾性システムの同定が 可能と考えられる.

\section{6. おわりに}

異方性システムのうち比較的多く見受けられる横等 方三次元粘弾性システムの同定法について考察した. まず，実験面に適合した自由境界面を含む境界条件を 設定した上で，横等方性システムのグリーン関数を導 出した. 自由境界面を含むシステムの固有值は複雑に 関係づけられているため，固有值を近似陽表示するこ とによりシステム同定を可能にした.つぎに，ディジ タルシミュレーションにより, この近似の妥当性とそ れに基づく同定法の正当性について検証した.ささら に，本同定法を異方性を示す実システムへ適用し，パ ラメータ推定を行った，得られた推定波形は，実測応 答波形の主要部を大略説明しており, 各パラメータ推 定值むシステムのものとして妥当であった．これらの 結果より, 本方法は異方性を示す三次元双曲形分布定
第 21 巻 第 12 号

数系の同定に有用であると考えられる.

今後の課題としては，応答波形の特徵からパラメー タの概略值を簡単に把握すること．また，実測応答波 形と推定波形の後部に少しずれが見られるが，乙れら については, 理論, 実験の両面からさらに検討を加え る必要がある。

終りに, 卒業研究としてご協力いただいた本学学 生, 森山博教, 日高 稔, 堀本孝治君に謝意を表しま す.

1) D. L. Russell: Controllability and Stabilizability Theorem for Linear Partial Defferential Equations. Recent Progress and Open Questions, SIAM Rev. 20, 639/739 (1978)

2) N. Weck: A Remark on Controllability for Symmetric Hyperbolic Systems in One Dimension, SIAM J. Control and Opti., 20-1, 1/8 (1982)

3) M. P. Polis, R. E. Goodson and M. J. Wozny: On Parameter Identification for Distributed System Using Galerkin's Criterion, Automatica, 9, 53/64 (1973)

4) P. N. Paraskevopoulos and A.C. Bounas: Distributed Parameter System Identification via Walsh Functions, Int. J. Syst. Sic., 9, 75/83 (1978)

5) 沖田 豪, 小林康秀, 田中正吾：過渡応答を用いた三次 元双曲形分布定数系の同定, 電気学会論文誌, 101-C-6, 145/152 (1981)

6) R.F.S. Hearmon: An Introduction to Applied Anisotropic Elasticity, Oxford University Press (1961)

7) S. G. Lekhnitskii: Theory of elasticity of an Anisotropic Elastic Body, Holden-Day (1963)

8) S.R. Moghe and C.C. Hsiao: Stress Distribution in Anistropic Visco-Elastic Hollow Sphere, J. Apl. Mech., 32, 31/36 (1965)

9) W. Flugge: Viscoelasticity, Blaisdell Publishing Company (1967)

10）山田嘉昭：塑性・粘弾性，培風館（1980)

11) 松本浩之: 線形粘弾性体の衝撃応答, 日本機械学会論文 集，48-A-436，1475/1480 (1982)

12) K.C. Valanis and A. Iowa: Some Exact Wave Propagation Solutions in Viscoelastic Materials: Acta Mechanica, 4-2, 170/190 (1967)

13）川井良次, 中川紀寿, 船越昭範：衝撃を受ける粘弾性材 料の波動に関方石研究，日本機械学会論文集，48-A-425, 101/109 (1982) 